
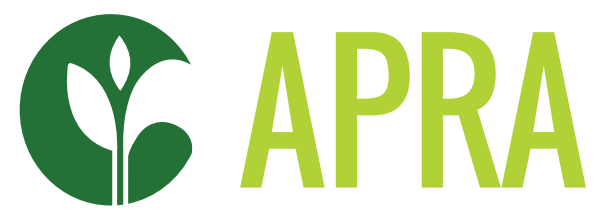

Agricultural Policy Research in Africa

\title{
THE INFLUENCE OF SUNFLOWER COMMERCIALISATION AND DIVERSITY ON WOMEN'S EMPOWERMENT: THE CASE OF IRAMBA AND MKALAMA DISTRICTS, SINGIDA REGION
}

Devotha B. Mosha, John Jeckoniah, Aida Isinika and Gideon Boniface 


\section{CONTENTS}

Acknowledgements.

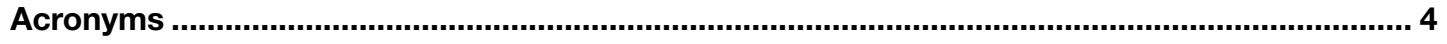

Executive summary ................................................................................................................ 6

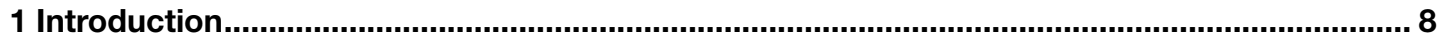

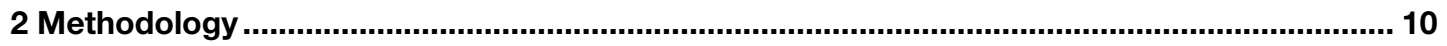

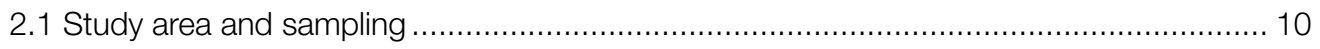

2.2 Data collection methods, type and source ................................................... 10

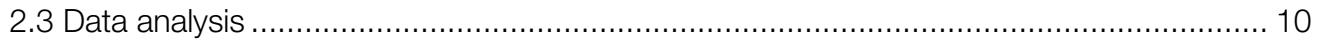

3 Findings and discussion ..................................................................................................... 13

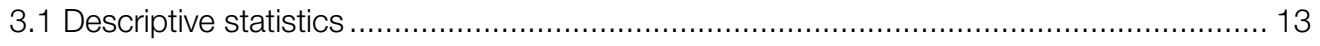

3.2 Women's empowerment in the sunflower value chain ...................................... 13

3.3 Poverty status in relation to sunflower commercialisation ................................... 16

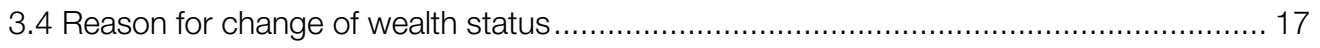

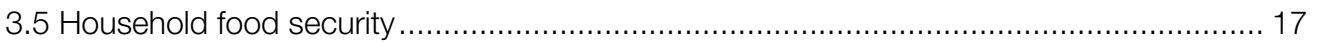

3.6 The contribution of sunflower commercialisation to women's empowerment.................. 18

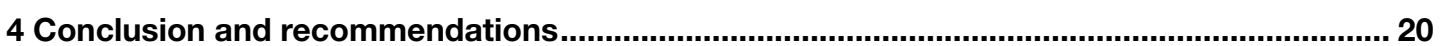

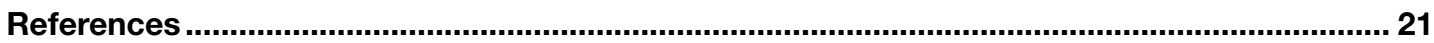

Tables

Table 3.1 Land area (ha) under sunflower production in 2017/18 by category of farmer ....... 13

Table 3.2 Sunflower output (kg) and productivity (kg/ha) during the 2017/18 farming

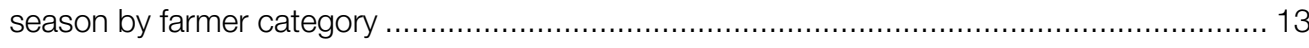

Table 3.3 Descriptive statistics for women's empowerment.................................... 14

Table 3.4 Multidimensional poverty index across farmer categories .............................. 16

Table 3.5 Household food security across farmer categories.................................. 17

Table 3.6 The influence of $\mathrm{HCl}$ and SCl on women's empowerment:

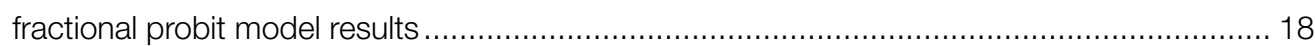

Figures

Figure 3.1 Change of wealth status by gender of household head ............................. 16

Boxes

Box 3.1 Women's empowerment through collective action: the case of Isene Village...... 15 


\section{ACKNOWLEDGEMENTS}

The research team sincerely thank the Department for International Development (DFID) UK (now the Foreign, Commonwealth \& Development Office, FCDO) for funding this research. We are also grateful to all respondents in the Iramba and Mkalama districts who unreservedly provided their time to share with us their information and life experiences in relation to sunflower commercialisation, and the challenges they face. The researchers hope that the challenges related to sunflower commercialisation are identified and addressed, to help farmers and development agencies formulate solutions. It is further anticipated that the initiatives to address the challenges will contribute towards women's empowerment through improved livelihood outcomes, not only in the surveyed districts but across Singida Region and other potential regions that grow sunflowers. The research team acknowledges the feedback and contributions received from all the APRA members for reviewing earlier drafts of this paper, and from the coordination secretariat at the Institute of Development Studies (IDS), University of Sussex, UK. The authors remain solely responsible for any errors herein.

Devotha B. Mosha, is a Senior Research Fellow, John Jeckoniah, is an Associate Professor, and Aida Isinika, is a Professor at the Sokoine University of Agriculture, in Morogoro, Tanzania. Gideon Boniface is an independent researcher.

This working paper is funded with UK aid from the UK government (Foreign, Commonwealth \& Development Office - FCDO, formerly DFID). The opinions are the authors and do not necessarily reflect the views or policies of IDS or the UK government. 


\section{ACRONYMS}

\begin{tabular}{|c|c|}
\hline APRA & Agricultural Policy Research in Africa \\
\hline CND & cumulative normal density \\
\hline CWEI & composite women's empowerment index \\
\hline DAICO & District Agricultural Irrigation and Cooperative Officer \\
\hline DFID & Department for International Development \\
\hline ESA & Agricultural Development Economics \\
\hline FAO & Food and Agricultural Organization of United Nations \\
\hline FAOSTAT & Food and Agricultural Organization of the United Nations Statistical Database \\
\hline FCDO & Foreign, Commonwealth \& Development Office \\
\hline FGD & focus group discussion \\
\hline FHH & female-headed household \\
\hline $\mathrm{HCl}$ & household commercialisation index \\
\hline HDI & Human Development Index \\
\hline IDS & Institute of Development Studies \\
\hline IFAD & International Fund for Agricultural Development \\
\hline IGA & income-generating activity \\
\hline IIRR & International Institute of Rural Reconstruction \\
\hline KI & key informant interview \\
\hline LGA & local government authority \\
\hline МHн & male-headed household \\
\hline MPI & multidimensional poverty index \\
\hline MSF & medium-scale farmers \\
\hline NGO & governmental organisation \\
\hline
\end{tabular}




$\begin{array}{ll}\text { RLDC } & \text { Rural Livelihood Development Company } \\ \text { SC } & \text { Sunflower commercialisation } \\ \text { SCI } & \text { Sunflower commercialisation indices } \\ \text { SPSS } & \text { Statistical Package for Social Science } \\ \text { SSA } & \text { sub-Saharan Africa } \\ \text { SSF } & \text { Small-scale farmers } \\ \text { STATA } & \text { Statistics and Data } \\ \text { UN } & \text { United Nations } \\ \text { URT } & \text { United Republic of Tanzania } \\ \text { VICOBA } & \text { Village Community Bank }\end{array}$


There is a growing body of literature that argues that normally women derive little benefit from cash crops. Some of the barriers leading to women having less benefit from cash crop value chains include cultural norms and power differences in access to, and control over, resources among actors in value chains (SOFA and Doss 2011; Ganle, Afriyie and Segbefia 2015). It is also argued that women's participation in different forms of collective action help women to increase benefits to them through their increased agency, hence enabling them to utilise existing and diverse options for their empowerment. This paper explores how women have benefited from their engagement in sunflower commercialisation and how culture has influenced changes in access to, and control over, resources, including land, for their empowerment.

The study was conducted in Iramba and Mkalama districts in Singida Region as part of the Agricultural Policy Research in Africa (APRA) consortium under work stream 2 (WS2). We adopted a mixed methods approach where both qualitative and quantitative data were collected during the same period. Quantitative surveys involved 601 farm households (14 per cent female headed and 86 per cent male headed) selected randomly from a population of 15 villages. A household questionnaire was used to interview the sampled farm households. Qualitative data were collected using focus group discussions (FGDs) from each of the 15 villages, and key informant (KI) interviews involved a total of 205 respondents (77 per cent being male).

Qualitative data were analysed using content analysis with the constant comparison technique, where information was transcribed verbatim and organised into themes representing the key drivers of sunflower commercialisation and women's empowerment. Thereafter, the emerging themes were organised, compared, and used to present our findings. A descriptive statistical analysis was computed from the quantitative data. The level of women's empowerment was established by developing the composite women's empowerment index, and then the degree of sunflower commercialisation attained by different farmers was computed using Microsoft Excel, SPSS, and STATA software. The fractional probit model was adopted to estimate the influence of agricultural commercialisation on women's empowerment.

The findings indicate that sunflower production and productivity is generally low. There is a significant difference in the mean yield of sunflowers between men and women ( $P>0.05)$.

Overall, women's participation in decision-making at the household level was higher (80 per cent). The majority of women (66.7 per cent) participated in decision-making with regard to agricultural production. The majority of them (58.2 per cent) also spent more time on production activities. We found a significant difference in women's empowerment between Iramba and Mkalama districts in terms of women's participation in decision-making for agriculture production and control over land. There was a higher mean score for women's participation in decision-making in productive activities in Mkalama (71.6 per cent) compared to Iramba District (62.4 per cent). Likewise, women in Mkalama recorded a higher score on the control of land (29.2 per cent) compared to only 16.5 per cent in Iramba District. The engagement of women farmers in sunflower commercialisation through interactions with other sellers, traders, and middlemen has increased the networking and sharing of information and experiences on marketing, and social and economic development aspects. This is different from women engaging in other crops because in sunflower commercialisation, women have opportunities to meet with different stakeholders, which helps them to learn about the industry and increases their confidence and bargaining power.

The engagement of women in sunflower commercialisation has enabled them to increase their income and therefore fulfil their basic needs including food, shelter, and education and health services. In addition, some women have benefited from employment in sunflower-processing mills, and engagement in winnowing and sorting sunflower seeds, while others have been able to invest in new income-generating activities (IGAs) such as extracting oil from crude oil residue (ugido).

Furthermore, women in the study area have used different strategies to increase their control and 
ownership of income accrued from IGAs. They have participated in different forms of collective actions, including joining social self-help groups and village saving and credit groups such as village community banks (VICOBA). Women's participation in these collective action groups increases their confidence and self-esteem which contributes towards women's social and economic empowerment.

Generally, sunflower commercialisation has played a positive and significant role in household livelihood improvement. For example, over the past five years, 37 per cent of farm households reported an improvement in their wealth status, 39 per cent reported it had remained unchanged, while 24 per cent of respondents reported that their wealth status had declined. Livelihood improvement for farming households was related to their participation in sunflower commercialisation.

However, sunflowers have not been the only source of livelihood improvement. There are a number of nonfarm income sources including those from other crops that have also contributed to livelihood improvement. Generally, farmers whose livelihoods have improved are those who were able to switch to crops or other economic activities other than sunflower production. Farmers have been able to expand their sunflower farms as well as other crops (cotton, sorghum, and millet) and obtain higher yields.

A comparison of wealth rank changes by gender revealed that female-headed households (FHHs) experienced a higher proportion of decline in wealth (31 per cent) than male-headed households (MHHs) (17 per cent). Also, a higher proportion of $\mathrm{FHHs}$ remained unchanged (44 per cent) compared to their male counterparts (27 per cent). There was little difference in the proportion of households whose livelihoods improved across the two studied districts. Three reasons are attributed to their wealth status decline; old age, prolonged illness, and single parent roles.

Old age and prolonged illness resulted in a reduction in sunflower and other crop production. A few FHHs opted to reduce sunflower production due to a shortage of land or prolonged drought. Other households, however, switched to other crops including maize, chickpeas, and cotton, as these crops were deemed to be more profitable during some years. It was noted that a reduction in sunflower production was not always associated with livelihood decline. However, being a single parent and needing to save and accumulate wealth from different sources also contributed to a decline in the wealth status of $\mathrm{FHHs}$.

In terms of food security, the mean score on food security was higher for $\mathrm{MHH}$ s than $\mathrm{FHHs}$, implying that $\mathrm{MHH}$ sere more likely to be food secure than their female counterparts. There was also a significant difference across commercialisation and food security levels, whereby those with low levels of sunflower commercialisation were also less food secure. In addition, there was a significant difference in the proportion of households meeting dietary diversity among small-scale farmers (SSFs) and medium-scale farmers (MSFs) such that MSFs were more likely to meet dietary diversity requirements than their SSF counterparts (57.3 per cent and 40.8 per cent for MSFs and SSFs respectively). There was no significant difference by sex among those meeting dietary diversity requirements, implying that the sex of the head of the household was not an important predictor in meeting household dietary diversity.

Results from the regression analysis revealed that, although sunflower commercialisation was related to women's empowerment in terms of improved livelihood ( $P>0.05)$, household commercialisation had a significant relationship with women's empowerment $(\mathrm{P}<0.05)$, implying that diversification of the source of income such as the combination of crops and other IGAs was a more important predictor for women's empowerment than focusing on sunflower commercialisation alone.

Sunflower commercialisation has benefited almost everyone in the study area. However, it is evident that a combination of economic activities is necessary for livelihood improvement, and also for women's empowerment. Women derive fewer benefits from their engagement in sunflower commercialisation compared to men due to cultural norms. Cultural norms tend to exclude women from decisionmaking regarding marketing and the expenditure of farm proceeds. Therefore, this study recommends that local government authorities (LGAs) and other value chain actors increase support for empowering women's initiatives. This can be done by formalising women's self-help groups and helping them to enforce existing laws and regulations to promote the equal ownership and control of resources. Such efforts will in due course weaken some of the negative cultural norms, which undermine ongoing initiatives to address negative cultural practices. 


\section{INTRODUCTION}

Across the globe and in developing countries in particular, women play a key role in agriculture. Women account for about 43 per cent of the agricultural labour force in developing countries and they produce up to 80 per cent of all food consumed in African countries (Palacios-Lopez, Christiaensen and Kilic 2015; FAO 2019). Although women are a focal point for agricultural development, the gender equality goal is framed in terms of women's productive capacity. Embedded within the development discourse is a conversation that advocates for increasing women's rights on the basis of improved food production (Sell and Minot 2018). An unequal distribution is illustrated by the unequal statistics regarding the following: the division of labour between women and men; the different needs of women and men in the world of work; the sex-based division of access to, and control over, resources and benefits; and opportunities and constraints in both the social and economic environment (Chant 2016).

Across less developed countries (Croppenstedt et al. 2013), West Africa (Peterman et al. 2011), sub-Saharan Africa, and Tanzania (Locher 2016), women tend to produce less than men. This gender gap is not due, however, to any inherent difference between men and women. According to Sell and Minot (2018), most wealth is in the hands of men, and most agricultural resources and inputs are controlled by men. Land is the most important production asset which, in many contexts, falls under the custodianship of men. In fact, studies show that when 'all else is equal', there is no difference in men's and women's agricultural productivity (Peterman et al. 2011). However, 'all else' is rarely equal between genders. This inequality is evident worldwide, but manifests differently by place (FAO 2019). Studies show that in developing countries and agrarian systems, 'all else' often refers to women's limited access to critical productive resources for agriculture (Chant 2016) and in decisionmaking power. The gender pay gap still remains wide especially in agricultural production, processing, and commercialisation.

Emerging research spanning the 1990s to the present time shows that the unequal sharing of resources and benefits between men and women is founded in cultural origins and traditions, especially among patriarchal systems where men are portrayed as being superior to women (KIT, Agri-ProFocus and IIRR 2012; Ganle et al. 2015; Jayachandran 2015). Despite the fact that in Tanzania men and women are granted equal rights to own land (URT 1999), the enforcement of such rights depends on the sociocultural context which is enshrined in the customary land rights and which favours men (Locher 2016). Therefore, for women to secure and exercise their rights to land, decisionmaking regarding crop production, and the sharing of related benefits depends on their level of agency and empowerment (SOFA and Doss 2011).

However, government and development partners in most developing countries have increasingly shown commitment to women's empowerment. They have realised that empowering women is a win-win situation that benefits both women and men (Zakaria 2016; Balayar 2018). Women's empowerment is fast becoming a key instrument in promoting women's abilities to achieve their rights and access to production resources, which subsequently increases agricultural productivity and economic growth (Palacios-Lopez et al. 2015; Quisumbing et al. 2014). Likewise, there is a growing body of literature which recognises that women's empowerment in cash and high-value crops such as rice and sunflowers could increase income, improve livelihoods, and reduce poverty (Von Bülow and Sørensen 1993; Darity 1995). According to FAO (2019), women who are empowered have the same access to productive resources as men, they tend to perform better in agricultural production, and hence tend to increase yields on their farms by 20-30 per cent.

The importance of sunflowers as a cash crop has grown slowly during the last thirty years, particularly in the Singida and Dodoma regions. In Singida Region, sunflowers are the leading cash crop and engage about 57 per cent of the farmers (Kombe et al. 2017). According to survey data from the Iramba and Mkalama districts, 71 per cent of the farmers grew sunflowers in $2017 / 18$. Of the total sunflowergrowing population across both districts, 74.4 per cent were female-headed households and 69.4 per cent were male-headed households. Following this survey, many sunflower commercialisation initiatives are now being undertaken by both government and non- 
governmental organisations which aim to transform the sunflower subsector towards improved livelihoods and poverty reduction.

The history of Singida Region shows that sunflowers were regarded as 'a woman's crop', owing to their low returns and lack of market value, similar to other crops produced for domestic consumption such as groundnuts and sweet potatoes. However, as sunflower production, processing, and marketing has improved in the last twenty years, the crop has changed from being a subsistence crop to being the main cash crop. Men have resumed control of the income accrued from sunflower production (Isinika and Mwajombe 2019). This has resulted in the partial satisfaction of household needs and hinders women optimising the benefits from agricultural commercialisation for the wellbeing of the family. This situation often disheartens women, leading them to 'hang in' or 'hang out' in the sunflower value chain.

A growing body of literature recognises that much of the economic transformation and livelihood improvement observed in Singida Region during the last twenty years can be largely attributed to the expansion of sunflower production, processing, and commercialisation (Zilihona et al. 2013: 70; Mgeni et al. 2018; Isinika and Mwajombe 2019). Similarly, as sunflower production has expanded over the years, involving different gender social groups including men and women; youth and elders; and poor and rich households, other livelihood pathway options have also emerged within the village, ward, and town. However, when considering the previous large body of literature on women's empowerment, there is hardly any research on whether sunflower commercialisation and diversity has made any contribution to women's empowerment and if any benefits have translated into livelihood improvement.

The livelihood pathways adopted by men and women in the sunflower value chain and how they benefit women in Singida Region has not been documented. Using data from a larger study on sunflower commercialisation in Singida Region under the Agricultural Policy Research in Africa (APRA) programme, ${ }^{1}$ this paper attempts to narrow the aforementioned knowledge gaps. The paper examines how women negotiate a better position, participation, and benefits in sunflower commercialisation and how this influences women's empowerment in the region. The paper further explores how such changes are achieved and accepted in the context of a prevailing patriarchal sociocultural system that undervalues women's roles in commercialisation strategies.

1 The Agricultural Policy Research in Africa (APRA) programme is a five-year research consortium that is working to identify the most effective pathways to agricultural commercialisation that empower women, reduce rural poverty, and improve food security and nutrition security in sub-Saharan Africa. 
Section 2 starts by providing general information on the study area and the rationale for selection. This section discusses the sampling procedure, data sources, and research methods applied in both the data collection and data analysis.

\subsection{Study area and pling}

Data for this paper were obtained from the APRA work stream 2 (WS2) research conducted in Iramba and Mkalama districts in Singida Region, which is located in central Tanzania. The districts were purposively selected due to their long history of sunflower production. From the two districts, 15 villages (eight in Iramba and seven in Mkalama) were randomly selected using a simple random sampling technique. These are: Kidaru, Wembere, Tyeme, Mugundu, Mgungia, Ng'ang'uli, Luono, and Zinziligi in Iramba District, and Dominiki, Nkalakala, Kisuluiga, Nduguti, Lukomo, Isene, and Mwanga villages in Mkalama District. The villages were selected based on their past record of high levels of sunflower production and their potential for production in the future. Simple random sampling procedures were employed to select households that were involved in the household surveys using a structured questionnaire. The households were further categorised into small- and medium-scale producers in which those cultivating less than five hectares were categorised as small-scale and those cultivating more than five hectares as medium-scale.

\subsection{Data collection methods, type and}

\section{source}

The study adopted a mixed data collection approach where both qualitative and quantitative data were collected during the same period. Quantitative data were collected using a household survey. Qualitative data were collected using focus group discussions (FGDs) and key informant interviews (KIs). The FGDs comprised a total of 205 individuals: 77 per cent men and 23 per cent women. The composition of FGDs in each village included a village government chairperson, a village executive officer, an agricultural extension officer, and a representative from the farmers based on social categories (age, sex, wealth, class, and leadership position). Key informants included village leaders, government employees, elders, traders, and processors who were selected based on their positions and experience of the topics under research. Qualitative data collection explored the timeline of key events for sunflower commercialisation including the impacts of drivers. In this paper, we focus on the impact on women's empowerment, institutional and cultural factors in relation to the political economy of sunflowers, and how different categories of community members have gained or lost from sunflower commercialisation.

\subsection{Data analysis}

Qualitative data were analysed using a content analysis approach, with the constant comparison technique where data were transcribed verbatim and organised into themes representing the key drivers of sunflower commercialisation and women's empowerment in the area. Thereafter, the emerging themes were organised and compared. Additionally, the information from key informant interviews, wealth ranking, and timelines enabled researchers to establish the trend of sunflower commercialisation since the 1970s, when most of the surveyed villages started growing sunflowers with an increasingly commercial inclination.

Descriptive statistics were computed from the quantitative data. The level of women's empowerment was established by developing the composite women's empowerment index (CWEI), and then the degree of sunflower commercialisation (SC) attained by each farmer was computed using Microsoft Excel, SPSS, and STATA software. To analyse the impact of commercialisation on women's empowerment, the household bargaining model was used where empowerment in terms of women's bargaining power in decision-making and control over assets and income were used as proxy indicators for their empowerment. This is in line with what was proposed by Mabsout and van Staveren (2010).

To estimate the influence of agricultural commercialisation on women's empowerment, the fractional probit model was used since women's empowerment was expected to lie between 0 and 1 , and we assumed that the functional form of empowerment is a cumulative normal density (CND) function. The fractional probit regression model 
demonstrates the unique characteristic of taking into account the dependent variable expressed in fraction form, as well as having the ability to take care of the extreme values of 0 and 1 . This is recommended by Papke and Wooldridge (1996, 2008).

The model expresses the expected mean changes in the women's empowerment index (y) conditioned on the change of explanatory variables (xi), which includes the household commercialisation index (HCI). Mathematically, this can be represented as $E(y \mid x i)$. The specific model, which was used for analysis, is defined in Section 2.3.1.

\subsubsection{Model specification}

The fractional probit regression model is defined as:

$$
L(\beta ; y, x)=\prod_{j}^{N}=\left(\Phi\left(x_{i}^{\prime} \beta\right)^{y i}\left[1-\Phi\left(x_{i}^{\prime} \beta\right)\right]^{1-y i}\right)
$$

Equation 1

Where $L_{j}$ is the function to be maximised, representing the expected value of the empowerment index attained by regressing $y_{i}$ against the specified explanatory variables; is the standard normal cumulative density function; $\Phi\left(X_{I / J} \beta\right)$ is a model which can take various functional forms based on the distribution function of dependent variable $\left(y_{i}\right) ; \mathrm{N}$ is the sample size, $w_{j}$ denotes the optional weights, $X_{i j}$ is the ith covariate or independent variable for the $j^{\text {th }}$ household. If weights $\left(w_{j}\right)$ are introduced to reflect the share of covariates on the empowerment index, then the log transformation of equation (1) is presented in equation 2.

$$
\begin{aligned}
& i \eta L(\beta ; y, x)=\sum_{j}^{N}={ }_{1} W_{j} y_{j} \operatorname{In}\left\{\Phi\left(x_{i}^{\prime} \beta\right)\right\}+w_{j} \\
& \left(1-y_{i}\right) \operatorname{In}\left\{1-\Phi\left(x_{i}^{\prime} \beta\right)\right\}
\end{aligned}
$$

Equation 2

In this study, $y$ is defined as the averaged women's empowerment index to be estimated, while the covariates $\left(x_{i}\right)$ include the $\mathrm{HCl}$ and other household characteristics such as sex of household head, age of household head, education level of household head, household size, total agricultural land accessed by the household, non-farm income, number of crops cultivated by a household, and whether the household owns cattle.

\subsubsection{Measuring women's empowerment}

The measurement of women's empowerment in this paper adopted the procedures outlined by Jeckoniah, Mosha and Boniface (2020) ${ }^{2}$ and Dancer and Hossain (2018).The level of women's empowerment in this paper was established using two approaches; the first approach used the mean score of the proxy indicators adopted for this study which included levels of productive resources (land ownership); participation in decisionmaking with respect to agriculture production; control over income; and time spent on production activities. Other proxy indictors measured the attainment of food security and participation in collective actions. ${ }^{3}$ The mean scores from each proxy indicator were used to construct a composite women's empowerment index scale. The scores from the women's empowerment index were further categorised into low (0.0-0.5), medium (0.6-0.7), and high (0.8-1). This categorisation is in line with the guidance of the Human Development Index (Alkire and Santos 2013: 19; UNDP 2018: 123) where the score on the Human Development Index also varies between the value of zero and one.

The second approach used qualitative data collected during the FGDs which captured women's own experience with regard to their intrahousehold parity and position under different livelihood improvement interventions undertaken during the course of sunflower commercialisation.

\subsubsection{Measuring sunflower commercialisation}

The household commercialisation index $(\mathrm{HCl})$ and sunflower commercialisation indices $(\mathrm{SCl})^{4}$ were developed using the procedures adopted by Isinika and Mwajombe (2019) in which the SCl was computed as a percentage of the sunflowers marketed out of what was produced. The $\mathrm{HCl}$ was developed by computing the percentage of all crops that were marketed. This methodological approach has been recommended by other scholars including Muriithi and Matz (2015) and Von Braun (1994) (cited in Cazzuffi, McKay and

2 See Jeckoniah et al. (2020) for a detailed description of the measurement of women's empowerment regarding rice commercialisation in Mngeta Division, Kilombero District, Tanzania.

3 Collective action is any form of organised social or political act carried out by a group of people in order to address their needs.

4 The detailed methodology is presented in another APRA Working Paper from Tanzania titled: Does Rice Commercialisation Impact on Livelihood? Experience from Mngeta in Kilombero District, Tanzania (Isinika et al. 2020). 
Perge 2018: 25). The sunflower and household commercialisation indices varied from zero, where nothing was sold, to one, where all the sunflowers or all the crops produced were sold. A comparison of these indices was made across farm size categories, sex of farmer, level of empowerment, and attainment of food security and poverty status, as measured by the multidimensional poverty index (MPI). The scores were divided into quintiles, which were then used as explanatory variables together with other household socioeconomic characteristics, to account for variation in the empowerment index attained by women, which was the dependent variable in a regression model.

\subsubsection{Measuring livelihood and its indicators}

The level of household welfare was computed using the most commonly used approaches in the literature where these proxies are used: income, assets, food security, subjective wellbeing, or multidimensional poverty (Alkire et al. 2016). This paper adopted the approach established by Isinika and Mwajombe (2019) as guided by APRA (2017) ${ }^{5}$ in which the household livelihood wellbeing level was estimated using the multidimensional poverty index (MPI) as proposed by Alkire and Santos (2013: 19) and Alkire et al. (2016). Therefore, the MPI represents the proportion by which a household is deprived, with higher scores representing more deprivation, and hence more poverty.

5 The MPI was constructed using three dimensions which collectively have ten indicators of poverty. The dimensions are health, education, and living standards. Nutrition and child mortality constitute the health dimension; child school attendance and years of schooling indicators together constitute the education dimension; and cooking fuel, sanitation, water, house floor, assets, and electricity constitute the living standards dimension. The indicators of health and education each have a weight of $1 / 6$, while those of living standards have a weight of $1 / 8$ each in contributing to poverty. The weight was given on a household which was considered to be deprived in a particular indicator. A household is considered to be MPI-poor if they have a sum weighted deprivation score of $1 / 3$ of all weighted indicators. 


\section{FINDINGS AND DISCUSSION}

\subsection{Descriptive statistics}

Sunflower cultivation in the Iramba and Mkalama districts as it is in many other districts in the region is dominated by smallholder farmers (Kombe et al. 2017). The findings in Table 3.1 show that the average acreage under sunflower cultivation is $0.9 \mathrm{ha}$ and $2.5 \mathrm{ha}$ for small- and medium-scale farmers respectively. As experienced in other rural farming households in Tanzania (URT 2012: 539) men had a relatively bigger area (1.3ha) under sunflower cultivation in the study area than women (0.7ha). The mean scores of the land under sunflower cultivation among different categories of farmers were all statistically significant.

The findings as presented in Table 3.2 show that sunflower production and productivity is generally low. The mean yield was $631.2 \mathrm{~kg} / \mathrm{ha}$. Smallholder farmers recorded a relatively higher yield per hectare compared to MSFs although the difference in the mean yield was not statistically significant. The findings presented also reveal that there was a significant difference in the mean yield of sunflowers amongst men and women ( $P>0.05)$. Similar differences in productivity across gender have also been reported by other scholars (Peterman et al. 2011; Njuki et al. 2006). As alluded to earlier, low levels of women's access to, and control over, productive resources and empowerment is associated with low productivity.

\subsection{Women's empowerment in the}

\section{sunflower value chain}

A descriptive analysis of women's empowerment as presented in Table 3.3 indicates that overall, women's participation in decision-making at the household

Table 3.1 Land area (ha) under sunflower production in $2017 / 18$ by category of farmer

\begin{tabular}{|c|c|c|c|c|c|c|}
\hline \multirow[t]{3}{*}{ Item } & \multicolumn{6}{|c|}{ Farmer category } \\
\hline & \multicolumn{2}{|c|}{ Farm size category } & \multirow{2}{*}{$\begin{array}{l}\text { Significance of } \\
\text { difference of the } \\
\text { mean }\end{array}$} & \multicolumn{2}{|c|}{ Sex category } & \multirow{2}{*}{$\begin{array}{l}\text { Significance of } \\
\text { difference of the } \\
\text { mean }\end{array}$} \\
\hline & SSF & MSF & & Male & Female & \\
\hline Mean land area & 0.9 & 2.5 & $3,316,481$ & 1.3 & 0.7 & $\mathrm{~F}=8.0^{\star \star \star}$ \\
\hline Median & 0.8 & 2.0 & 48973944.89 & 0.8 & 0.4 & \\
\hline Minimum & 0.01 & 0.2 & $52,290,426$ & 0.01 & 0.1 & \\
\hline Maximum & 4.15 & 18.2 & 38 & 18.2 & 3.6 & \\
\hline
\end{tabular}

Source: Authors' own, based on data from an APRA Tanzania survey (2018)

Table 3.2 Sunflower output $(\mathrm{kg})$ and productivity $(\mathrm{kg} / \mathrm{ha}$ ) during the $\mathbf{2 0 1 7 / 1 8}$ farming season by farmer category

\begin{tabular}{|c|c|c|c|c|c|c|}
\hline \multirow{2}{*}{$\begin{array}{l}\text { Farmer category } \\
\text { Farm size }\end{array}$} & \multicolumn{3}{|c|}{ Sunflower yield (kg/ha) } & \multicolumn{2}{|c|}{$\begin{array}{l}\text { Sunflower output (kg/ } \\
\text { household) }\end{array}$} & \multirow[b]{2}{*}{$\begin{array}{l}\text { Significance or } \\
\text { the mean }\end{array}$} \\
\hline & Mean & Median & $\begin{array}{l}\text { Significance of } \\
\text { the mean }\end{array}$ & Mean & Median & \\
\hline SSF & 654.4 & 462.5 & $\mathrm{~F}=0.5$ & 426.5 & 288.0 & $\mathrm{~F}=8.0^{\star \star \star}$ \\
\hline MSF & 553.4 & 370.7 & & 1269.2 & 720.0 & \\
\hline \multicolumn{7}{|l|}{ Sex } \\
\hline Male & 657.6 & 458.1 & $F=1.26$ & 653.9 & 370.0 & $\mathrm{~F}=8.5^{\star \star \star}$ \\
\hline Female & 475.3 & 415.1 & & 304.9 & 192.0 & \\
\hline Whole sample & 631.2 & 444.8 & & 603.4 & 336.0 & \\
\hline
\end{tabular}

Source: Authors' own, based on data from an APRA Tanzania survey (2018) 
level is higher (80.1 per cent) than any other sphere. Many participated in decision-making with regard to agricultural production as well as time spent on production activities at the household level (66.7 and 58.2 per cent respectively). The least scores were on control over land and participation in collective action (22.5 per cent and 17.8 per cent respectively). This finding compares well with most literature on rural Tanzania (Pedersen 2015; Moyo 2017) in which women's empowerment in terms of control over resources is still low.

While the land laws in Tanzania call for equality of men's and women's access to land (URT 1999; URT 2001), the level of progress towards equality for land access for women remains a challenge (Pedersen and Haule 2013; Pedersen 2015). The land laws in Tanzania suffer from inadequate enforcement and inherent contradictions, especially at the village level. For example, the Village Land Act provides that the customary right of occupancy is in every respect of equal status and effect to a granted right of occupancy. This disadvantages woman in two respects; firstly, most local customs do not recognise women's rights (instead, they favour men) and the government officials do not recognise customary land rights as being equal to statutory rights, and they may not respect the legal authorities of the village government over village land. Secondly, women are underrepresented in most village government institutions and committees. For example, it was found in this study that, while traditional land ownership by women was highly valued, in some villages, men were completely against its practices due to the outcome of land ownership after divorce or separation in which women continued to own the piece of land that she had been allocated. Hence, men's adoption of traditional land ownership by women has depended on marital stability.

Smallholder farmers had a higher mean score on the time spent on raising children, household chores, and looking after the sick at 61.3 per cent, compared to 44.8 per cent for MSFs. Since most of these kinds of activities within the household are undertaken by women (Laslett and Brenner 1989; Islam 2012), these findings, then, imply that women from SSFs spent relatively more time on these activities around the house than their MSF counterparts. This can partly be explained by the relative lack of ownership of productive assets in SSFs and hence less labour-saving tools to relieve women from back-breaking household chores, which must be done in addition to child-bearing and caring for the sick.

The analysis shows that there was a significant difference in women's empowerment between the Iramba and Mkalama districts in terms of women's participation in decision-making for agriculture production and control over land. There was a higher mean score for participation in decision-making in productive activities in Mkalama (71.6 per cent) compared to in Iramba District (62.4 per cent). Likewise, women in Mkalama recorded a higher score on control of land (29.2 per cent) compared to only 16.5 per cent in Iramba District.

Table 3.3 Descriptive statistics for women's empowerment

\begin{tabular}{|c|c|c|c|c|c|c|}
\hline \multirow[t]{2}{*}{ Farmer category } & \multicolumn{3}{|c|}{ Women's empowerment indicators } & \multicolumn{2}{|c|}{$\begin{array}{l}\text { Sunflower output ( } \mathrm{kg} / \\
\text { household) }\end{array}$} & \multirow[b]{2}{*}{$\begin{array}{l}\text { Collective } \\
\text { action }\end{array}$} \\
\hline & $\begin{array}{l}\text { Decision- } \\
\text { making on } \\
\text { agricultural } \\
\text { production }\end{array}$ & $\begin{array}{l}\text { Control } \\
\text { and } \\
\text { ownership } \\
\text { of land }\end{array}$ & $\begin{array}{l}\text { Decision- } \\
\text { making on } \\
\text { household } \\
\text { income }\end{array}$ & $\begin{array}{l}\text { Time spent } \\
\text { on childcare, } \\
\text { household } \\
\text { chores, etc. }\end{array}$ & $\begin{array}{l}\text { Attainment } \\
\text { of food } \\
\text { security }\end{array}$ & \\
\hline \multicolumn{7}{|l|}{ Farm size } \\
\hline SSF & 65.6 & 23.3 & 80.5 & 61.3 & 42.6 & 18.2 \\
\hline MSF & 66.9 & 17.7 & 77.9 & 44.8 & 77.1 & 16.7 \\
\hline Significance & $X^{2}=0.05$ & $X^{2}=1.4$ & $X^{2}=0.3$ & $X^{2}=8.8^{\star \star \star}$ & $X^{2}=37.3^{\star \star \star}$ & $X^{2}=0.1$ \\
\hline \multicolumn{7}{|l|}{ Sex of head } \\
\hline Male & 62.5 & 13.5 & 77.0 & 57.9 & 31.6 & 16.7 \\
\hline Female & 91.0 & 74.4 & 97.4 & 60.3 & 51.8 & 18.0 \\
\hline Significance & $X^{2}=24.3^{\star \star \star}$ & $X^{2}=141.2^{\star \star \star}$ & $X^{2}=17.3^{\star \star \star}$ & $X^{2}=0.2$ & $X^{2}=10.6^{\star \star \star}$ & $X^{2}=0.07$ \\
\hline \multicolumn{7}{|l|}{ District } \\
\hline Iramba & 62.4 & 16.5 & 78.3 & 58.4 & 51.3 & 14.7 \\
\hline Mkalama & 71.6 & 29.2 & 82.1 & 58.0 & 46.2 & 21.2 \\
\hline Significance & $X^{2}=5.06^{\star \star}$ & $X^{2}=12.2^{\star \star \star}$ & $X^{2}=1.17$ & $X^{2}=0.01$ & $X^{2}=1.36$ & $X^{2}$ \\
\hline Whole Sample & 66.7 & 22.5 & 80.1 & 58.2 & 48.9 & 17.8 \\
\hline
\end{tabular}

Source: Authors' own, based on data from an APRA Tanzania survey (2018) 
Women's empowerment was also expressed in terms of the benefit to women, especially from their engagement in sunflower commercialisation activities which enabled them to accomplish their tasks without many difficulties. For example, consumers have benefited from the availability of sunflower cooking oil close to rural communities. Another form of benefit relates to some women who have benefited by engaging in new income-generating activities such as re-processing crude oil residue (ugido) to extract the remaining oil for personal use or for sale to neighbours. Other women gain employment providing winnowing and sorting services before the sunflower seed is put into the oil press.

This study also found that women have devised diverse strategies to increase their control and ownership of income accrued from different income-generating activities. Such efforts included joining women's collective action groups such as self-help groups, as well as savings and credit groups. It was frequently reported in the FGDs that women's participation in these collective action groups increased their confidence and self-esteem, which helped them to identify the means to challenge the barriers to their increased control of productive assets such as land. As argued by Alsop, Bertelsen and Holland (2006: 25), women's empowerment at the individual level is important but it makes much more impact when it is attained at community level. This happens when likeminded men and/or women come together through collective action groups and start a movement towards desired change. This study found that through the use of collective action initiatives, women in some villages were able to overcome traditions that hinder women's control over income and other assets including land (see Box 3.1).

The case of women's empowerment as presented by the women's initiatives in Isene Village confirms the assertion that women's participation in different forms of collective actions do increase women's agency, hence them utilising existing options. In this case, it was found that an increase in women's agency helped them to make alternative use of the traditionally prescribed land use for the production of crops for market, and to have control of the income accrued from their productive activities.

It was also reported that the success and transformation of gender roles as women are empowered depends also on marital stability and shared goals. While nsoza was recognised and accepted in many study villages, it faced some resistance and rejection by men in other villages. For example, the nsoza has been challenged by men in Zinziligi Village in Iramba where, as everywhere else, there is a higher incidence of divorce due to marital disharmony, and men no longer practise nsoza for fear of losing land to their wives in the case of a divorce. Nsoza means 'a piece of land allocated to wives'. It is a cultural right for women to have a piece of land for their own production, in the same way that they have control of the income and expenditure of the land.

\title{
Box 3.1 Women's empowerment through collective action: the case of Isene Village
}

\begin{abstract}
In Isene Village located in Mkalama District, women had been actively engaged in sunflower farming and processing although they did not benefit equitably. To overcome the inequity, especially regarding the sharing of benefits accrued from sunflower production, women in Isene Village decided to widen the scope of their self-help groups to include saving and lending for development purposes. Other groups soon followed this initiative pioneered by the Amani group, and the number of groups increased to seven such groups in the village. Women used a traditional land tenure system (the nsoza) commonly practiced amongst the Wanyiramba tribe, to their advantage, instead of just producing crops for household consumption, and hence they gained more control over the use of the land. The adapted women's groups engaged in VICOBA and used the money to lend to men and women in the village during lean months in exchange for sunflowers during the harvesting season. Women used the money accrued from this business to buy household amenities that improved the quality of life for each group member, such as nice clothes, domestic utensils, mattresses, and roofing iron sheets. Women also used their share of the profits and savings to buy clothes for their husbands - henceforth, women decided to concentrate on buying items that would directly improve the quality of life. All this has been possible due to the power of collective action from savings and lending groups, with seed capital from sunflower production. Such collective action does not happen automatically but requires strategic engagement with spouses and sustaining a common interest among members.
\end{abstract}

Source: Isinika and Mwajombe (2019). 


\subsection{Poverty status in relation to sunfllower commercialisation}

The level of poverty was established by developing the multidimensional poverty index and through qualitative data analysis. The findings presented in Table 3.4 show that there was a significant difference in the level of poverty among SSFs and MSFs; the SSFs had a mean score of 82.3 per cent on the MPI index, implying that SSFs were more likely to be categorised in as MPI-poor than their MSF counterparts (70.2 per cent). There was an insignificant difference in the level of MPI-poor between men and women (79.5 per cent and 82.1 per cent for women and men respectively). There was no significant difference in the level of poverty and levels of scores on the sunflower commercialisation index, implying that there was no causal inference between sunflower commercialisation and the poverty level as measured by the MPI.

The findings from the FGDs revealed that sunflower commercialisation has brought a range of benefits to different people which have also improved their livelihood. This study found that there was a rise and fall in the number of households that experienced an improvement in livelihood as reported in Figure 3.1. There have been some changes in livelihood status over the past five years. This was closely related to farmers' engagement in sunflower commercialisation in which some households have declined, remained the same, or improved their livelihood status in relation to this participation.

For the whole sample for FGD participants, about 37 per cent of the households experienced improved wealth,

Table 3.4 Multidimensional poverty index across farmer categories

\begin{tabular}{|l|l|l|l|}
\hline Farmer category & $\begin{array}{l}\text { Proportion of households } \\
\text { not MPI-poor }\end{array}$ & $\begin{array}{l}\text { Proportion of MPI-poor } \\
\text { households }\end{array}$ & Significance of difference \\
\hline SSFs & 17.7 & 82.3 & $X^{2}=5.90^{\star \star}$ \\
\hline MSFs & 29.8 & 70.2 & \\
\hline Sex of household head & & & $X^{2}=0.21$ \\
\hline Male & 20.5 & 79.5 & \\
\hline Female & 17.9 & 82.1 & \\
\hline SCI & & & \\
\hline Zero & 15.9 & 84.1 & $X^{2}=5.14$ \\
\hline Low & 15.9 & 84.1 & \\
\hline Medium & 27.7 & 72.3 & \\
\hline High & 16.5 & 83.5 & \\
\hline Whole sample & 20.1 & 79.9 & \\
\hline
\end{tabular}

${ }^{* * *}=P<0.01$ (significant at 1 per cent); ${ }^{* *}=P<0.05$ (significant at 5 per cent); ${ }^{*}=P<0.1$ (significant at 10 per cent).

Source: Authors' own, based on data from an APRA Tanzania survey (2018)

Figure 3.1 Change of wealth status by gender of household head

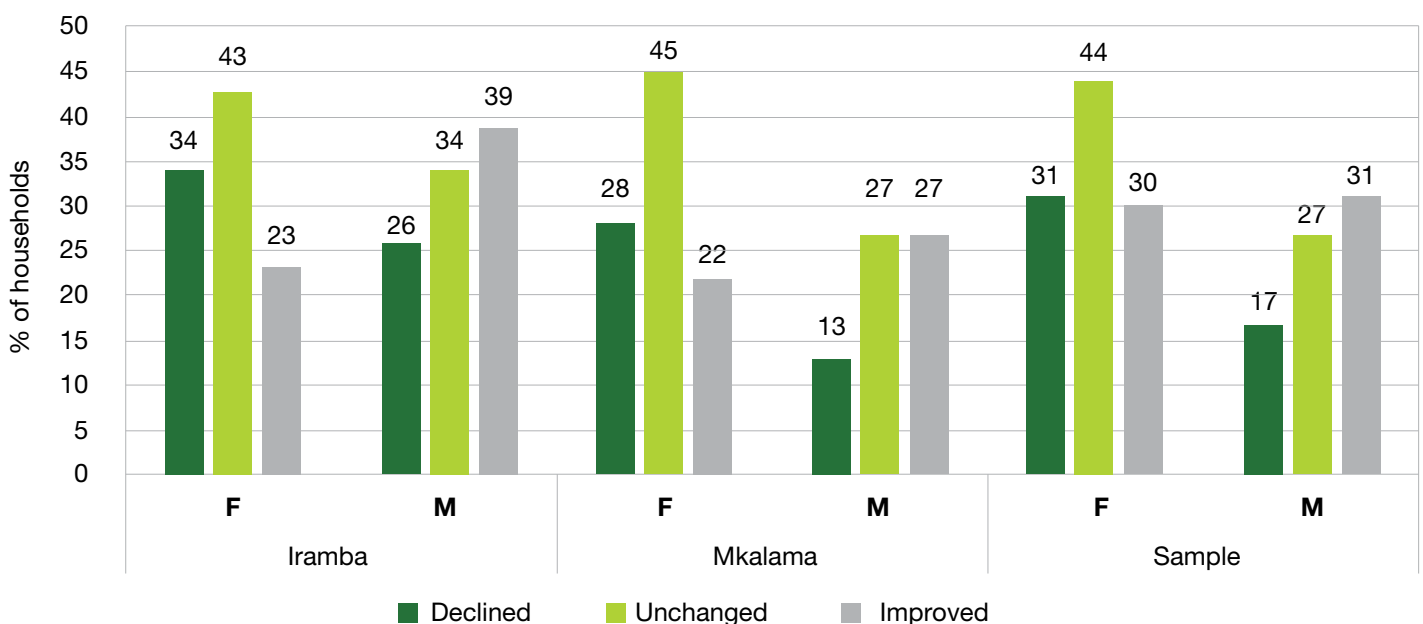

Source: Authors' own, based on data from an APRA Tanzania survey (2018) 
39 per cent remained unchanged, while 24 per cent experienced a decline in wealth. The trend of change across different strata was not uniform across villages. About 67 per cent of households in the high wealth rank experienced an improvement, compared to only 52 per cent and 23 per cent in the middle and low wealth ranks respectively. The proportion of households who had experienced improved wealth was higher in Mkalama for high- and middle-wealth ranks (69 per cent and 58 per cent respectively compared to 64 per cent and 45 per cent respectively for Iramba District). Generally, the households categorised in the higher wealth rank were more likely to report an improvement in wealth rank as opposed to their poor-ranked counterparts.

\subsection{Reason for change of wealth status}

The reasons that were given by FGD participants for the changes in wealth status tended to be similar across villages. These included advanced age and prolonged illness, especially among the rich category, whereas laziness, excessive alcohol drinking, and disharmony within the household were frequently mentioned as causes for the middle- and poor-ranked households. Reduced sunflower production was mentioned in some villages to have contributed to livelihood decline. Some farmers had to reduce sunflower production due to a shortage of land, the low market price of sunflower seed, and prolonged drought. Others, however, switched to alternative crops including maize, chickpeas, and cotton, which were deemed to be more profitable during some years. Generally, those who were able to switch to other crops or other production activities were those whose wealth rank had improved due to sunflower production.
Some have been able to expand their sunflower farms as well as other crops (cotton, sorghum, and millet), obtaining higher yields in the process.

A comparison of wealth rank changes by gender revealed that $\mathrm{FHH}$ s experienced a higher proportion of decline in wealth (31 per cent) than $\mathrm{MHHs}$ (17 per cent). Also, a higher proportion of $\mathrm{FHH}$ remained unchanged (44 per cent) compared to their male counterparts (27 per cent). There was little difference in the proportion of households whose livelihoods improved across the two studied districts. These findings compare well with other literature in SSA and Tanzania, where the level and incidence of poverty has a gender dimension, with women being in some disadvantaged categories (Chant 2008; Kessy et al. 2011: 50; Brown and van de Walle 2020).

Female and male-headed households reported having to face different risk factors in relation to sunflower production, at different points in their lifetimes. It is further argued that $\mathrm{FHH}$ tend to be more vulnerable during their child-bearing years due to the workload, while men tend to be more vulnerable in their old age due to sickness (Isinika and Mwajombe 2019). Empowerment is frequently reported in the literature to be related to food security. This present study also explores access to food security from a gender perspective in the context of sunflower commercialisation.

\subsection{Household food security}

Household food security is an important indicator of livelihood improvement as well as a good proxy indicator for empowerment (Dancer and Hossain 2018). In this

Table 3.5 Household food security across farmer categories

\begin{tabular}{|c|c|c|c|c|}
\hline Farmer category & $\begin{array}{l}\text { Proportion of } \\
\text { food-secure } \\
\text { households }\end{array}$ & $\begin{array}{l}\text { Significance of } \\
\text { difference }\end{array}$ & $\begin{array}{l}\text { Proportion of } \\
\text { households } \\
\text { meeting minimum } \\
\text { dietary diversity }\end{array}$ & $\begin{array}{l}\text { Significance of } \\
\text { difference }\end{array}$ \\
\hline \multicolumn{5}{|l|}{ Farm size } \\
\hline SSFS & 42.6 & $X^{2}=37.29^{\star \star \star}$ & 40.8 & $X^{2}=8.6^{\star \star \star}$ \\
\hline MSFS & 77.1 & & 57.3 & \\
\hline \multicolumn{5}{|c|}{ Sex of household head } \\
\hline Male & 31.6 & $X^{2}=10.62^{\star \star \star}$ & 37.8 & $X^{2}=1.25$ \\
\hline Female & 51.8 & & 44.8 & \\
\hline \multicolumn{5}{|l|}{ SCl } \\
\hline Zero & 55.6 & & 45.3 & \\
\hline Low & 46.5 & $X^{2}=17.63^{\star \star \star}$ & 44.6 & $X^{2}=1.08$ \\
\hline Medium & 66.7 & & 45.9 & \\
\hline High & 39.4 & & 39.4 & \\
\hline Whole sample & 48.9 & & 43.8 & \\
\hline
\end{tabular}

${ }^{\star \star \star}=$ significant at 1 per cent; ${ }^{\star \star}=$ significant at 5 per cent; ${ }^{*}=$ significant at 10 per cent.

Source: Authors' own, based on data from an APRA Tanzania survey (2018) 
study, it was found that for the whole sample, only 48.9 per cent were categorised as a food-secure household and only 43.8 per cent were able to meet the minimum dietary diversity requirements (Table 3.5). There was a significant difference in food security among SSFs and MSFs, where SSFs were more likely to be categorised as being a food-secure household. There was a gender dimension in the attainment of food security as reflected in the significant difference in food security among men and women. The mean score on food security was higher for men than women, implying that $\mathrm{MHH}$ s were more likely to be food secure than their $\mathrm{FHH}$ counterparts. There was also a significant difference across commercialisation and food security levels, whereby those with a low level of sunflower commercialisation were also less food secure.

In addition, there was a significant difference in the proportion of households meeting dietary diversity among SSFs and MSFs, such that MSFs were more likely to meet dietary diversity requirements than their SSF counterparts (57.3 per cent and 40.8 per cent for MSFs and SSFs respectively). There was no significant difference among those meeting dietary diversity requirements, implying that the sex of the head of the household was not an important predictor in meeting household dietary diversity.

\subsection{The contribution of sunflower commercialisation to women's empowerment}

The findings on the contribution of sunflower commercialisation to women's empowerment from the qualitative data were consistent with what was found using econometric models. The fractional probit regression model was used to estimate the influence of sunflower commercialisation as well as household commercialisation on women's empowerment. Household commercialisation was developed to include all the crops grown and sold by the particular household, thus capturing the contribution of, and diversified approach to, the farm and non-farm incomes of the farming household. The findings as presented in Table 3.6 reveal that the relationship between sunflower commercialisation and women's empowerment was not statistically significant $(P>0.05)$, while the relationship of household commercialisation and women's empowerment was statistically significant $(P<0.05)$.

The findings further show that women's empowerment increased with scores on the $\mathrm{HCl}$. The important predictors for women's empowerment in both household commercialisation and sunflower commercialisation indices were: participation in nonfarm activities; living in a household which is femaleled; the age of the head of household; and being in a small-scale farmer household $(P<0.05)$. Increasing household size had a negative relationship to women's empowerment, implying that as the family size increases, there is a higher chance for women in that particular household to be less empowered.

The contribution of sunflower commercialisation to women's empowerment is associated with women having an increased source of income. This simplifies women's ability to meet the household's needs and manage their duties with less difficulty. However, sunflower commercialisation alone fails to empower

Table 3.6 The influence of $\mathrm{HCl}$ and $\mathrm{SCl}$ on women's empowerment: fractional probit model results

\begin{tabular}{|l|l|l|l|}
\hline Variables & $\begin{array}{l}\text { Model (1) HCl vs } \\
\text { composite women's } \\
\text { empowerment index } \\
\text { (CWEI) }\end{array}$ & Variables & $\begin{array}{l}\text { Model (2) SCl vs composite } \\
\text { women's empowerment index } \\
\text { (CWEI) }\end{array}$ \\
\hline $\mathbf{H C l}$ & $\mathbf{0 . ( 0 . 0 0 1 )}$ & $\mathbf{S C l}$ & $\mathbf{- 0 . 0 0 1}(\mathbf{0 . 0 0 1 )}$ \\
\hline Male head & $-0.378^{\star \star \star}(0.066)$ & Male head & $-0.307^{\star \star \star}(0.080)$ \\
\hline Age head & $-0.008^{\star \star \star}(0.002)$ & Age head & $-0.008^{\star \star \star}(0.002)$ \\
\hline Household size & $-0.036^{\star \star \star}(0.008)$ & Household size & $-0.042^{\star \star *}(0.010)$ \\
\hline Medium-scale farmer & $-0.121^{\star \star}(0.056)$ & Medium-Scale farmer & $-0.127^{\star \star}(0.061)$ \\
\hline Youth farmer & $-0.156^{\star \star}(0.064)$ & Youth farmer & $-0.162^{\star \star}(0.078)$ \\
\hline Non-farm income & $0.000^{\star \star *}(0.000)$ & Non-farm income & $0.000^{\star \star}(0.000)$ \\
\hline Own livestock & $0.027(0.048)$ & Own livestock & $0.026(0.060)$ \\
\hline Constant & $0.953^{\star \star *}(0.161)$ & Constant & $1.092^{\star \star \star}(0.197)$ \\
\hline Observations & 497 & Observations & 358 \\
\hline
\end{tabular}

Note: Robust standard errors in parentheses. ${ }^{* *}=p<0.01 ;{ }^{* *}=p<0.05 ;{ }^{*}=p<0.1$.

Source: Authors' own, based on data from an APRA Tanzania survey (2018) 
women because they still have less bargaining power in decision-making with regard to marketing and income accrued from the sale of sunflowers. This kind of situation also echoes the findings of Sell and Minot (2018) and Isinika and Mwajombe (2018). The findings of their research indicate that this trend exists in many cash crops, in which women, despite their contribution to production activities, don't have the final say on how much or what type of crop to market and also on the use of income. Evidence indicates that farmers who participate in decision-making are better able to profit from market integration as their wealth cushions the vulnerability that comes with neoliberal shifts from subsistence farming to marketing (Chant 2016).

Moreover, the findings indicate that the household commercialisation index had more impact on determining women's empowerment. This can be explained by the diversity of income sources. Women's income is from various sources and is connected to participation in collective action such as saving and credit groups (VICOBA). They also accrue income from the sale of crops from their traditionally allocated own plots (nsoza). Women have control over this income and its expenditure. Therefore, the above findings suggest that greater access to alternative income resources is connected to higher sunflower commercialisation, which leads to women's empowerment and positive benefits for the household.

Women's participation in non-farm activities as well as household and socioeconomic characteristics have also been reported in the literature to be important predictors of women's empowerment (Mahmud et al. 2018). Increasing the household size had a negative relationship to women's empowerment, implying that as the family size increases, there is a higher chance of a woman in that particular household to be less empowered. Similarly, this result is in agreement with the findings of Gupta and Sharma (2004) and is consistent with findings based on the Tanzania household budget survey that indicated the larger the household size the poorer it is (URT 2020). In contrast, some scholars have argued that a larger household size was an important predictor for improved wellbeing in many rural areas (Ayoola Oni and Adenike Adepoju 2014). Others have reported that a larger household size was not an important factor or reduced the probability of the household being categorised as having improved wellbeing (Upadhyay et al. 2014). Therefore, we conclude that the influence of household size on women's empowerment and wellbeing depends on the quality of labour and the family age structure. Family labour is the most important factor of production in many rural settings. 


\section{CONCLUSION AND RECOMMENDATIONS}

This paper explores how women have benefited from their engagement in sunflower commercialisation and how diversity in the livelihood initiatives adopted has influenced changes in access to, and control over, assets including land, and on their economic empowerment. The level of sunflower production and productivity in the study area is generally low, and $\mathrm{FHHs}$ have a lower mean yield than $\mathrm{MHH}$. This is attributed to the presence of gender differences between women and men. Women have low access to the means of production and bargaining power in decision-making at the household level.

Women's and men's involvement in sunflower production and commercialisation does indeed provide benefits, especially on increased yield and income at the household level. Sunflower commercialisation influences women's empowerment through gaining experience of market integration for sunflower production and sharing in collective actions. A combination of initiatives for livelihood improvement including diversity of enterprise portfolio of income is more important for women's empowerment rather than focusing on sunflower commercialisation alone.

The level of women's empowerment was higher in aspects related to decision-making in agriculture production, household income, and on time spent on child-bearing and raising children. Women are relatively less empowered with regard to food security, control and ownership of land, and participation in collective action. It is unsurprising that collective action in self-help groups and VICOBA had the potential to increase women's agency, which is translated into an increasing confidence and self-esteem that leads to empowerment. This policy message in particular is a necessary step for affirmative action to challenge the status quo imbedded in culture and traditions that limit women's movement or freedom to decide and participate in developmental interventions. There is a need for local government authorities and other value chain actors to increase support for those women's initiatives that empower them. 


\section{REFERENCES}

Alkire, S. and Santos, M. (2013) Measuring Acute Poverty in the Developing World: Robustness and Scope of the Multidimensional Poverty Index, OPHI Working Paper 59, Oxford: Oxford Poverty \& Human Development Initiative, http://dx.doi.org/10.2139/ssrn.2296819 Pp 19 (accessed 18 May 2021)

Alkire, S. et al. (2016) 'The Global Multidimensional Poverty Index (MPI): 5-year Methodological Note', OPHI Briefing Note 37, Oxford: Oxford Poverty and Human Development Initiative, University of Oxford (accessed 4 June 2021)

Alsop, R.; Bertelsen, M. and Holland, J. (2006) Empowerment in Practice: From Analysis to Implementation, Washington DC: World Bank

APRA (2017) 'Research Programme Consortium 2017: Commercialisation, Women's Empowerment and Poverty Reduction', APRA Inception Phase Outcome Indicators Papers, submitted to the UK Department for International Development by the Institute of Development Studies, 28 February

Ayoola Oni, O. and Adenike Adepoju, T. (2014) 'Analysis of Rural Households' Wellbeing in Nigeria: A Capability Approach', International Journal of Social Economics 41.9: 760-79

Balayar, R.B. (2018) 'Women's Empowerment in High Value Cash Crop Activities in the Rural Hills of Nepal', PhD dissertation, Department of Sociology, lowa State University (accessed 3 June 2021)

Brown, C. and van de Walle, D. (2020) Headship and Poverty in Africa, CGD Working Paper 531, Washington DC: Center for Global Development (accessed 9 May 2020)

Cazzuffi, C.; McKay, A. and Perge, P. (2018) The Impact of Commercialization of Rice on Household Welfare in Rural Vietnam, WIDER Working Paper 2018/130, Helsinki: United Nations University World Institute for Development Economics Research

Chant, S. (2016) 'Women, Girls and World Poverty: Empowerment, Equality or Essentialism', International Development Planning Review 38.1: 1-24

Chant, S. (2008) 'The "Feminisation of Poverty" and the "Feminisation" of Anti-Poverty Programmes: Room for Revision?', Journal of Development Studies 44.2: 165-97

Croppenstedt, A.; Goldstein, M. and Rosas, N. (2013) Gender and Agriculture: Inefficiencies, Segregation, and Low Productivity Traps, Policy Research Working Paper 6370, Washington DC: World Bank

Dancer, H. and Hossain, N. (2018) Social Difference and Women's Empowerment in the Context of the Commercialisation of African Agriculture, APRA Working Paper 8, Brighton: Future Agricultures Consortium

Darity, W. (1995) 'The Formal Structure of a Gender-Segregated Low-Income Economy', World Development 23.11: 1963-68 (accessed 4 June 2020)

FAO (2019) 'Women in Agriculture: Closing the Gender Gap for Development', The State of Food and Agriculture 2010-11, Rome: Food and Agriculture Organization of the United Nations

Ganle J.K.; Afriyie, K. and Segbefia, A.O. (2015) 'Microcredit: Empowerment and Disempowerment of Rural Women in Ghana', World Development 66: 335-45

Isinika, A.C. and Mwajombe, K. (2019) 'Qualitative Report. APRA Tanzania: Work Stream 2 (WS2)', unpublished report 
Isinika A.C and Mwajombe, K. (2018) 'Qualitative Report. APRA Tanzania: Work Stream 1 (WS 1)', unpublished report

Isinika, A.C. et al. (2020) Does Rice Commercialisation Impact on Livelihood? Experience from Mngeta in Kilombero District, Tanzania, Brighton: Future Agricultures Consortium

Islam, S. (2012) 'Intra Household Labour Distribution and Role of Women in Family Decision Making Process', IOSR Journal of Humanities and Social Science 1.4: 8-15 (accessed 5 June 2020)

Jayachandran, S. (2015) 'The Roots of Gender Inequality in Developing Countries', Annual Review of Economics 7.1: 63-88 (accessed 30 May 2020)

Jeckoniah, J.; Mosha, D.B. and Boniface, G. (2020) Does Rice Commercialisation Empower Women? Experience from Mngeta Division in Kilombero District, Tanzania, APRA Working Paper 34, Brighton: Future Agricultures Consortium

KIT, Agri-ProFocus and IIRR (2012) Challenging Chains to Change: Gender Equity in Agricultural Value Chain Development, Amsterdam: Royal Tropical Institute, KIT Publishers

Kombe, C. et al. (2017) Potentiality of Sunflower Sub-Sector in Tanzania, Bank of Tanzania Working Paper 10, Dodoma: Bank of Tanzania

Laslett, B. and Brenner, J. (1989) 'Gender and Social Reproduction: Historical Perspectives', Annual Review of Sociology 15: 381-404 (accessed 5 June 2020)

Locher, M. (2016) 'How Come Others are Selling our Land?' Customary Land Rights and the Complex Process of Land Acquisition in Tanzania', Journal of Eastern African Studies 10.3: 393-412, DOI: 10.1080/17531055.2016.1250890 (accessed 25 May 2021)

Mabsout, R. and van Staveren, I. (2010) 'Disentangling Bargaining Power from Individual and Household Level to Institutions: Evidence on Women's Position in Ethiopia', World Development 38.5: 783-96

Mahmud, M.; Otsuka, K.; Sawada, Y.; Tanaka, M. and Tanaka, T. (2018) 'Non-Farm Sector Growth and Female Empowerment in Bangladesh', in Y. Sawada, M. Mahmud and N. Kitano (eds), Economic and Social Development of Bangladesh: Miracle and Challenges, Cham: Palgrave Macmillan

Mashindano, O.; Rweyemamu, D. and Charle, P. (2011) Poverty Escape Routes in Central Tanzania: Coping Strategies in Singida and Dodoma Regions, Vol. III, ESRF Discussion Paper 40, Dar es Salaam: Economic and Social Research Foundation

Mgeni, C.P.; Müller, K. and Sieber, S. (2018) 'Sunflower Value Chain Enhancements for the Rural Economy in Tanzania: A Village Computable General Equilibrium-CGE Approach', Sustainability 11.1: 75

Moyo, K.J. (2017) 'Women's Access to Land in Tanzania: The Case of the Makete District', PhD thesis, School of Architecture and the Built Environment, Royal Institute of Technology (KTH), Stockholm (accessed 3 June 2021)

Muriithi, B.W. and Matz, J.A. (2015) 'Welfare Effects of Vegetable Commercialization: Evidence from Smallholder Producers in Kenya', Food Policy 50: 80-91

Njuki, J.M.; Kihiyo, V.B.M.; O’Ktingati, A. and Place, F. (2006) 'Productivity Differences between Male and Female Managed Farms in the Eastern and Central Highlands of Kenya', paper presented at the International Association of Agricultural Economists Conference, Gold Coast, 12-18 August (accessed 4 June 2021)

Palacios-Lopez, A.; Christiaensen, L. and Kilic, T. (2015) How Much of the Labor in African Agriculture is Provided by Women?, Policy Research Working Paper 7282, Washington DC: World Bank Group (accessed 30 May 2020)

Papke, L.E. and Wooldridge, J.M. (2008) 'Panel Data Methods for Fractional Response Variables with an Application to Test Pass Rates', Journal of Econometrics 145.1-2: 121-33

Papke, L.E. and Wooldridge, J.M. (1996) 'Econometric Methods for Fractional Response Variables with an Application to 401(k) Plan Participation Rates', Journal of Applied Econometrics 11.6: 619-32 
Pedersen, R.H. (2015) 'A Less Gendered Access to Land? The Impact of Tanzania's New Wave of Land Reform', Development Policy Review 33.4: 415-32 (accessed 9 May 2020)

Pedersen, R.H. and Haule, S. (2013) Women, Donors and Land Administration: The Tanzania Case, DIIS Working Paper 2013:19, Copenhagen: Danish Institute for International Studies

Peterman, A.; Quisumbing, A.; Behrman, J. and Nkonya, E. (2011) 'Understanding the Complexities Surrounding Gender Differences in Agricultural Productivity in Nigeria and Uganda', The Journal of Development Studies 47.10: 1482-1509

Quisumbing, A.R. et al. (eds) (2014) Gender in Agriculture: Closing the Knowledge Gap, Dordrecht: Springer

Sell, M. and Minot, N. (2018) 'What Factors Explain Women's Empowerment? Decision-Making among SmallScale Farmers in Uganda', Women's Studies International Forum 71: 46-55 (accessed 30 May 2020)

Sharma, B.R. and Gupta, M. (2004) 'Gender Based Violence in India: A Never-Ending Phenomenon', Journal of International Women's Studies 6.1: 114-23 (accessed 4 June 2021)

SOFA and Doss, C. (2011) The Role of Women in Agriculture, ESA Working Paper 11, Rome: Agricultural Development Economics (ESA) Division, Food and Agriculture Organization of the United Nations (accessed 26 May 2021)

UNDP (2018) Human Development Indices and Indicators: 2018 Statistical Update, New York NY: United Nations Development Programme

Upadhyay, U.D. et al. (2014) 'Women's Empowerment and Fertility: A Review of the Literature', Social Science \& Medicine 115:111-20

URT (2020) 2017-18 Household Budget Survey, Dodoma: National Bureau of Statistics, Ministry of Finance and Planning

URT (2016) Sunflower Sector Development Strategy: 2016-2020, Geneva: International Trade Centre Pp 97

URT (2012) National Sample Census of Agriculture Small Holder Agriculture (2007/2008). Volume II: Crop Sector, Dar es Salaam: NBS/Prime Minister's Office, Regional Administration and Local Governments, Ministry of Industries, United Republic of Tanzania

URT (2001) The Village Land Regulations, Dar es Salaam: The United Republic of Tanzania

URT (1999) The Land Act, 1999, Dar es Salaam: The United Republic of Tanzania

Von Bülow, D. and Sørensen, A. (1993) 'Gender and Contract Farming: Tea Outgrower Schemes in Kenya', Review of African Political Economy 20.56: 38-52, DOI: 10.1080 /03056249308703984 (accessed 24 May 2021)

Zakaria, H. (2016) 'The Drivers of Women Farmers' Participation in Cash Crop Production: The Case of Women Smallholder Farmers in Northern Ghana', The Journal of Agricultural Education and Extension 23.2: 141-58, DOI: 10.1080/1389224X.2016.1259115 (accessed 26 May 2021)

Zilihona, I.J.E.; Mwatawala, H.W. and Swai, E.Y. (2013) 'Sunflower Production and its Contribution to Poverty Reduction in Singida District, Tanzania', paper presented at REPOA's 18th Annual Research Workshop, Dar es Salaam, 3-4 April 
Mosha, D.B.; Jeckoniah, J.; Isinika, A. and Boniface, G. (2021) The Influence of Sunflower Commercialisation and Diversity on Women's Empowerment: The Case of Iramba and Mkalama Districts, Singida Region, APRA Working Paper 59, Brighton: Future Agricultures Consortium

\section{(cc) BY-NC-ND}

This is an Open Access report distributed under the terms of the Attribution-Non Commercial-No Derivs 4.0 Unported (CC BY-NC-ND 4.0) Attribution - You must give appropriate credit, provide a link to the license, and indicate if changes were made. You may do so in any reasonable manner, but not in any way that suggests the licensor endorses you or your use. NonCommercial — You may not use the material for commercial purposes. NoDerivatives - If you remix, transform, or build upon the material, you may not distribute the modified material. You are free to: Share - copy and redistribute the material in any medium or format.

https://creativecommons.org/licenses/by-nc-nd/4.0/legalcode

If you use the work, we ask that you reference the APRA website (www.future-agricultures.org/apra/) and send a copy of the work or a link to its use online to the following address for our archive: APRA, Future Agricultures Consortium, University of Sussex, Brighton BN1 9RE, UK (apra@ids.ac.uk)

All APRA Working Papers go through a review process before publication.

\section{Cc) creative}

\section{DO YOU HAVE COMMENTS ON THIS PAPER?}

We would welcome your feedback on this working paper!

To provide brief comments, please follow this link to our short APRA Working Paper Feedback form: https://goo.gl/forms/1iVnXhhrlGesfR9

Agricultural Policy Research in Africa (APRA) is a programme of the Future Agricultures Consortium (FAC) which is

generating new evidence and policy-relevant insights on more inclusive pathways to agricultural commercialisation in sub-Saharan Africa. APRA is funded with UK aid from the UK Foreign, Commonwealth \&

Development Office (FCDO) and will run from 2016-2022.

The APRA Directorate is based at the Institute of Development Studies (IDS), UK (www.ids.ac.uk), with regional hubs at the Centre for African Bio-Entrepreneurship (CABE), Kenya, the Institute for Poverty, Land and Agrarian Studies (PLAAS), South Africa, and the University of Ghana, Legon. It builds on more than a decade of research and policy engagement work by the Future Agricultures Consortium (www.future-agricultures.org) and involves more than 100 researchers and communications professionals in Africa, UK, Sweden and USA. 